\title{
Cognitive Behavior Therapy Model with Cognitive Restructuring Techniques to Reduce Inmates' Pre- Release Social Anxiety Disorder
}

\author{
Alief Budiyono ${ }^{1}$, DYP. Sugiharto ${ }^{2}$, Anwar Sutoyo ${ }^{3}$, Maman Rachman $^{4}$ \\ \{alief@iainpurwokerto.ac.id ${ }^{1}$ \} \\ Institut Agama Islam Negeri (IAIN) Purwokerto, J1. A. Yani No. 40A Purwokerto 53126 Indonesia $^{1}$ \\ Universitas Negeri Semarang (UNNES), Jl. Kelud Utara III, Semarang 50237 Indonesia²,3,4
}

\begin{abstract}
Previous studies shows that almost all pre-release inmates experiencing anxiety. The anxiety generally occurs due to the inmates' thoughts about their stereotypes in society. This study aims to explore The Cognitive Behaviour Model with The Cognitive Restructuring Techniques that is used to reduce the Social Anxiety Disorder on inmates during Pre-release period. The level of anxiety is categorized into three, which are: severe, moderate and mild level. For this reason, the counsellor is obliged to provide an assistance and guidance in order to re-gain inmate's confidence and optimism especially when they return into the community. Results from this study are: 1) There is a positive response from inmates, in terms of personal understanding; 2) The reductions of problematic cognitions that interferes inmates' belief; 3) The loss of cognitive distortions which results in the capability of rationalizing the psychological issues.
\end{abstract}

Keywords: CBT Model, Cognitive Restructuring, Social Anxiety Disorder, Pre-release inmates.

\section{Introduction}

Crime is a societal issue that must be faced at all times and some data shows that there are high crime rates that exist, for example in the United States in 2002, around 902 men from 100,000 people would became prisoners, meanwhile total of women were around 6 [1]. In Indonesia 2017, the number of custodies was 71,761, and the number of inmates was 161,966, meanwhile total capacity of prisons and detention facilities to hold only as 122,114 people.

Besides this high occupancy, which related to the inmates' life decency and human rights, there are many other problems that must be settled, including pre-release anxiety among prison inmates. Previous studies shows that there are levels at inmate's pre-release anxiety [2] for example, states that almost all pre-release inmates experiencing anxiety, with the details of $37 \%$ experiencing severe anxiety, 28\% experiencing moderate and 34\% experiencing mild anxiety [2].

In fact, according to The University of South Wales, $36 \%$ of inmate's mental issues are anxiety and female prisoners have higher anxiety levels than men, which is $61 \%$ compared to $39 \%$. Meanwhile according to Shinkfield the level of anxiety is increasing as closer the inmate's release date, especially one month before the release [2]. 
Kusumaningsih explained that being an inmates or ex-inmates status could be an issue including after their release. These stereotypes causing self-confidence decreased and also causing more anxious especially assumption for not getting a decent job in the future. To reduce the anxiety level on pre-release inmates, this study wanted to assess The Cognitive Behavior Therapy (CBT) model with the Cognitive Restructuring techniques as an alternative solutions to resolve this [3].

The CBT method is considered as the proper method to reduce the anxiety issues on prerelease inmates [4]. A number of studies reported that CBT is an effective method in resolving anxiety disorder [5]. Although other studies also mentioned that there are some clients with anxiety who experiencing impairment and relapse [6] but as mentioned by O'Donohue dan Fisher, CBT is an important therapeutic paradigm, as has been repeatedly proven as an effective methods to resolve the psychological problems [7].

Moreover, Cognitive Restructuring seeks to modify and replace existing faulty or distorted thoughts. For example, for clients who believe that they have failed, could be encourage to challenge this belief by comparing and evaluating with other evidences that opposed to that belief [7].

This study will emphasize the application of CBT model with cognitive restructuring techniques in reducing anxiety on pre-release inmates. Hopefully this research would be the basis for counsellors to be able to help clients, or inmates in particular, to rediscover his life and live it with optimism without excessive anxiety.

\section{Methods}

The experimental design used in this study was chosen based on several assumption, which are: 1) The design in this study would generate a better result when compared with quasi-experimental design, 2) The design in this study is more appropriate in testing hypothesis in it because it provides more control so that the independent variables could be properly assessed, 3) In order to generate a better internal validity, this study was conducted using repeated measuring techniques [8].

The target population in this study was a small group with 10 members each group [9]. The number of prisoner sampled in this study were 20 people. The data used in this study are quantitative data collected through questionnaires regarding anxiety. The questionnaire data was taken before and after counselling using CBT model with cognitive restructuring techniques.

\section{Result and Discussion}

\subsection{Inmates' Pre-Release Social Anxiety Disorder.}

Anxiety is a form of neurotic helplessness, insecurity and immaturity feeling, also perpetually overwhelm with the daily life situation [10]. Reinforced by Kartini Kartono's opinion [11] anxiety is a feeling of worry and fear that are strong enough towards an unclear things and situation, as also stated by Sarlito Wirawan Sarwono that anxiety follows from an unknown or poorly defined threat [12]. 
The anxiety experienced by inmates generally classified as social anxiety disorder (SAD). American Psychiatric Association defines that SAD is debilitating and chronic illness characterized by a marked and persistent fear of one or more social performance situations, involving exposure to unfamiliar people or possibly scrutiny by others. As also mentioned by Baltaci dan Hamarta [13] social anxiety is a state of discomfort and stress that an individual experiences with the expectation that he/she will act inappropriately, make fool of himself/herself, leave a negative impression and evaluated by others in a negative way (stupid, loser, incompetent, insufficient etc.) in various social occasions.

People diagnosed with SAD is characterised by intense, persistent fear of being watch and judged by others, they will avoid social activities where they think they might have to do something that will embarrass them. Social anxiety is a condition where a person feels uncomfortable when present in public, this feeling is accompanied by shyness, that are characterized by clumsiness or stiffness or a tendency to avoid social interaction [14]. According to Smith [15] Social anxiety is a type of anxiety that occurs when a person is hanging out with other people or groups. A person who has high social anxiety level will show the reactions such as withdrawal and tense in social situations.

From the data collected it was found that many of the pre-release inmates experiencing social anxiety ranging from mild, moderate and severe levels. Most of these occur from fear of family rejection, negative stereotypes, and fear of not getting a decent job in the future.

\subsection{Factors Affecting Pre-release Inmates' Social Anxiety.}

According to Rape [16] social anxiety is caused when individuals enter into a new situation and need new adjustments to the situation, several factors that also influence social anxiety are: The way of thinking, too focused on people's attention, and avoidance.

In pre-release inmates, the ways of thinking is generally distorted. Many of them think that the family and the society will reject them, as negative stereotypes is hard to change.As the result of the excessive anxiety, his positive life orientation is reduced, even though his anxiety has never been proven truthful.

\subsection{Aspects of Social Anxiety}

La Grecca and Lopez [16], revealed about three aspects of social anxiety, which are: a) Negative evaluations. This evaluation is useful in identifying and explaining the inmates' way of thinking who are burdened with the negative thoughts. Negative evaluations also useful to understand the overall main problems which caused anxious of pre-release inmates, b) Avoidance and constrained in dealing with new situation and person. After the release, many of the ex-inmates seems to avoid social interaction, although this actually triggers the social anxiety presence continuously. Besides, there is also a response to reality that is irrational. c) The feelings of distress. Their stereotypes have a major influence on ex-inmates' actions and social attitudes. They tend to be reactive and emotional in responding to the worst possibilities that occurs on a social event. 


\subsection{CBT Model with Cognitive Restructuring Techniques to Overcome Pre-Release Inmates' Social Anxiety Disorder.}

CBT is a counseling theory popularized by Aaron T. Beck in 1960. In the beginning it is known as Cognitive Theraphy (CT) and then developed into Cognitive Behavior Theraphy (CBT). Cognitive therapy is an approach that combines the use of cognitive and behavioural techniques to help individuals modifying their moods and behaviour by changing their selfdestructive thoughts. The basic premise of cognitive therapy is that the way individuals feel or behave is largely determined by their thoughts. Cognitive therapy focuses primarily on selfharming thoughts that sometimes became a key role in creating a bad mood [17].

Aaron T. Beck defines CBT as a counseling approach designed to solve clients's problems by conducting cognitive restructuring of deviant behavior, negative thoughts and uncomfortable feelings that bring individuals into a more serious psychological problems, such as anxiety disorders and even depression. CBT is basically combines cognitive and behavioural therapy, and so that it has a component of understanding and regulation of emotions, functional analysis of behaviour and understanding towards the distorted way of thinking [18].

CBT guides clients to foster proactive thoughts and attitudes towards self, that adjust into the social environment, especially the place where the client lives. Therefore the specific model or technique that are suitable for this study is the Cognitive Restructuring Technique. The selection of this method is based on the background that social anxiety is a psychiatric illness that must be heal from the inner-self, as social anxiety could also affect the mind-set and interaction.

In addition, cognitive restructuring techniques have a basic principle that lies in negative beliefs about an individual. This basic belief involves individual cognition. Therefore, researchers consider that interventions involving individual cognitive functions such as cognitive behavioural counselling are more suitable for increasing self-confidence and positive self-concept as also providing solutions to client's social anxiety. This type of intervention focuses on identifying dysfunctional beliefs and turning them into a more positive beliefs.

According to [7] the best way in applying cognitive restructuring techniques is by conducting a multi-step process that involves as follows: a) Emergence of problematic cognitions, or known as automatic thoughts or negative automatic thoughts towards self, the world and the future; b) Formulating rational responses to the negative automatic thoughts; c) Approaching dialogue to identify and eliminate cognitive distortions which occurred in negative thoughts, beliefs, assumptions, false predictions, etc.[7].

As previous research conducted by Casey, Newcombe, and Oei found that increased panic self-efficacy and decreased catastrophic interpretation that occurred during treatment, were known to predict lower post-treatment panic severity [7].

\subsection{The Stages of Cognitive Behavioural Therapy (CBT) with Cognitive Restructuring techniques to reduce Inmates' Pre-Release Social Anxiety Disorder.}

Cognitive restructuring applies mind-centered learning principles. And designed to achieve a better emotional response by changing habitual tendencies or ways of thinking that cause people to make appraisals that are systematically biased in particular way [19]. Therefore, Cognitive restructuring strategy is based on two assumptions: 1) Irrational mind 
and cognitive distortion create self-defeating behaviour 2) Mind and self-assessment could be changed via personal views and cognition [19].

In this study, there are three stages of The CBT process to reduce anxiety on pre-release inmates, which are: the initial stage of therapy, the middle stage and the final stage of the therapy:

At the initial stage of the therapy, some steps include:

a. Developing a cognitive conceptualization about client's problem. The cognitive conceptualization aims to provide a stimulus for cognitive abstraction of the inmates before they are free to think openly and systematically of self-identification.

b. Developing and conducting a collaborative therapeutic relationships. This is to establish persuasive interpersonal communication between counselors with the prison inmates and another prison members.

c. Educating clients about their disorder and reducing client's distress problem through psycho-education. This point is used by counselors to conduct intensive psychological dialogue with inmates so that the counselor understands the main and fundamental issues.

d. Identifying various emotions. To help clients in identifying their emotions could be applied by the method of writing affirmations, which clients could share feelings and undefined personal issues.

e. Cognitive model explanation. The cognitive model in this context is cognitive restructuring model.

After the initial stages, there is a second stage which is in the middle stage of the therapy. At this point, the goal of the therapy is to achieve these things, as follows:

a. A collaborative therapeutic relationship, which means continuing collaborative therapeutic relationship by providing positive feedback and support towards the inmates so that they could understand the issue better;

b. A cognitive process model, It shifts the therapy from the automatic negative thoughts into transitional, and if necessary, to educates inmates about self-acceptance;

c. Assisting inmates to resolve problems, both during and after of the therapy period, expand the therapeutic responsibilities to the inmates, encourage inmates to become a personal therapist, encourage inmates to continue the therapy with inter-session assignments, preparing inmates to complete and to end the therapy.

And finally, the final stage of the therapy, the following objectives are:

a. A collaborative therapeutic relationship. Preparing inmates to end the therapy, with also considering other related issues.

b. A cognitive process model. Inmates conclusion of what has been learned, and understanding of the tools and techniques correctly. Rewards to the inmates's effort, decide when to end the therapy based on inmate's development of cognitive conceptualization, and exploring obstacles on ending the therapy session.

c. Helping inmates to resolve their issues during and after the therapy. Inmates become a personal therapist, also reduce tendencies of recurrence and to develop an action plan to resolve other potential problems in the future.

After completing all these three stages, the counsellor or therapist must ensure the mindset, thinking patterns, psychological conditions and behaviour of the inmates are increasingly positive. 


\section{Conclusion}

The type of anxiety which occurred on pre-release inmates is Social anxiety disorder. Most of these occur from fear of family rejection, negative stereotypes, and fear of not getting a decent job in the future. A Cognitive Behavioural Therapy with Cognitive Restructuring Techniques was applied which proved to be an effective solution. Result of this approach is the emergence of self-positive responses, reduction of problematic cognitions that decreased inmates' self-confidence and the loss of inmates' cognitive distortions and so as to be able to solve all the psychological problems rationally. 


\section{References}

[1] Ely. Fay, "An Analysis of Anger, Anxiety, and Self Esteem Factors in Relationto Severity of Crimes in Male Criminal Offenders," 2004.

[2] Utari, D.I., Fitria, N \& Rafiyah, I. "Gambaran tingkat kecemasan pada narapidana wanita menjelang bebas di Lembaga Pemasyarakatan Kelas II A Bandung,” J. Univ. Padjadjaran, 2011.

[3] Kusumaningsih, L. P. S. "Penerimaan Diri dan Kecemasan Terhadap Status Narapidana," Intuisi J. Psikol. Ilm., vol. Vol. 9 (3), 2017.

[4] Butler, et al. Mental Disorder in The New South Wales Prisoner Population. Australia: Jutice Health and University of New South Wales, 2005.

[5] Deacon. Brett J and Abramowitz JS., "Cognitive and Behavioral Treatments for Anxiety Disorders: AReview of Meta Analytic Finding,” J. Clin. Psychol., vol. Vol. 60 (4, pp. 429-441, 2004.

[6] Gainey, G. dan T. B. "A longitudinal examination of psychosocial impairment across the anxiety disorders," Psychol. Med., vol. 44, pp. 1691-1700, 2013.

[7] O’Donohue, William T dan Fisher, J. E. Cognitive Behavior Therapy; Prinsip-Prinsip Utama Untuk Praktik. Yogyakarta: Pustaka Pelajar, 2017.

[8] J. Creswell, Educational research, planning, conducting, and evaluating quantitative and qualitative. Upper Saddle River, NJ: Pearson Education.Inc, 2015.

[9] Capuzzi, D. \& Gross, D. R. Introduction to the Counseling Profession. Columbus, Ohio: Pearson Education.Inc, 2009.

[10] Yusuf, S. Mental Hygine: Terapi Psikospiritual untuk Hidup Sehat Berkualitas. Bandung: Maestro, 2009.

[11] Anisa, D. F. \& Ifdhil. "Konsep Kecemasan (Anxiety) pada Lanjut Usia (Lansia),” J. Konselor, vol. Vol. 5, No, 2016.

[12] Sarwono, S. W. Pengantar Psikologi Umum. Jakarta: Rajawali Press, 2012.

[13] Lailatussya'diyah, A. L. Hubungan Antara Kepercayaan Diri dengan Kecemasan Komunikasi Interpersonal. Yogyakarta: Kalimedia, 2014.

[14] Mutahari, H. "Hubungan Antara Kpercayaan Diri dengan Kecemasan Sosial pada Siswa Kelas VII SMP Negeri 2 Kalasan Tahun Ajaran 2015-2016,” J. Bimbing. dan Konseling, vol. Vol. 3, No, 2016.

[15] Lestari, E. S. "Hubungan Kecemasan Sosial dan Kematangan Emosi dengan Kematangan Seksual Remaja SMP di Kabupaten Bantul Yogyakarta," Psikopedagogia, vol. Vol.1, No., 2012.

[16] Pramitasari, S. \& A. D. A. "Hubungan Antara Konsep Diri Fisik dan Kecenderungan Kecemasan Sosial Remaja Awal," Psikol. Klin. dan Kesehat. Ment., vol. Vol. 3, No, 2014.

[17] Damayanti, Rika dan Nurjannah, P. A. "Pengaruh Konseling Kognitif Perilaku Dengan Teknik Restrukturisasi Kognitif Terhadap Harga Diri Peserta Didik Kelas VIII Di Mts N 2 Bandar Lampung,” J. Konseli Bimbing. dan Konseling, vol. Vol. III, 2016.

[18] Syafitri, D. U. "Terapi Kognitif Perilaku Pada Remaja dengan Gangguan Komorbid Perilaku Menentang dan Depresi yang Tinggal di Panti Asuhan,” Intuisi J. Psikol. Ilm., vol. 9, 2017.

[19] Erford, B. T. 40 Teknik yang Harus Diketahui Setiap Konselor. Yogyakarta: Pustaka Pelajar, 2017. 